\title{
Expression of Progesterone Receptor Membrane Component 1 (PGRMC1), Progestin and AdipoQ Receptor 7 (PAQPR7), and Plasminogen Activator Inhibitor 1 RNA-Binding Protein (PAIRBP1) in Glioma Spheroids In Vitro
}

\author{
Juraj Hlavaty, ${ }^{1}$ Reinhard Ertl, ${ }^{2}$ Ingrid Miller, ${ }^{3}$ and Cordula Gabriel ${ }^{1}$ \\ ${ }^{1}$ Institute of Anatomy, Histology and Embryology, University of Veterinary Medicine, 1210 Vienna, Austria \\ ${ }^{2}$ VetCORE, Facility for Research, University of Veterinary Medicine, 1210 Vienna, Austria \\ ${ }^{3}$ Institute of Medical Biochemistry, University of Veterinary Medicine, 1210 Vienna, Austria \\ Correspondence should be addressed to Cordula Gabriel; cordula.gabriel@vetmeduni.ac.at
}

Received 27 January 2016; Revised 14 April 2016; Accepted 27 April 2016

Academic Editor: Emeline Tabouret

Copyright (C) 2016 Juraj Hlavaty et al. This is an open access article distributed under the Creative Commons Attribution License, which permits unrestricted use, distribution, and reproduction in any medium, provided the original work is properly cited.

\begin{abstract}
Objective. Some effects of progesterone on glioma cells can be explained through the slow, genomic mediated response via nuclear receptors; the other effects suggest potential role of a fast, nongenomic action mediated by membrane-associated progesterone receptors. Methods. The effects of progesterone treatment on the expression levels of progesterone receptor membrane component 1 (PGRMC1), plasminogen activator inhibitor 1 RNA-binding protein (PAIRBP1), and progestin and adipoQ receptor 7 (PAQR7) on both mRNA and protein levels were investigated in spheroids derived from human glioma cell lines U-87 MG and LN-229. Results. The only significant alteration at the transcript level was the decrease in PGRMC1 mRNA observed in LN-229 spheroids treated with $30 \mathrm{ng} / \mathrm{mL}$ of progesterone. No visible alterations at the protein levels were observed using immunohistochemical analysis. Stimulation of U-87 MG spheroids resulted in an increase of PGRMC1 but a decrease of PAIRBP1 protein. Double immunofluorescent detection of PGRMC1 and PAIRBP1 identified the two proteins to be partially colocalized in the cells. Western blot analysis revealed the expected bands for PGRMC1 and PAIRBP1, whereas two bands were detected for PAQR7. Conclusion. The progesterone action is supposed to be mediated via membrane-associated progesterone receptors as the nuclear progesterone receptor was absent in tested spheroids.
\end{abstract}

\section{Background}

Glioblastoma multiforme (GBM, grade IV astrocytoma) is the most common and most aggressive malignant primary brain tumor in adults [1]. An effective treatment for GBM is not existent; the standard therapy is a combination of surgical resection of the tumor and subsequent chemotherapy with severe side effects resulting in a maximal increase of survival time for two months [2-4]. Therefore, improvement of the knowledge concerning this type of brain tumor to identify targets and therapeutic agents is voraciously needed.

Based on the knowledge that men are more often affected by primary GBM than women only until the age of menopause [5-7], a potential function of sex steroid hormones in GBM development was investigated in different studies.

In 2015, Atif et al. identified the steroid hormone progesterone as potential promising therapeutic agent in GBM [8]. In their study, the dose-dependent antitumor effects of progesterone were tested in well-established glioma cell lines in vitro and in subcutaneous U-87 MG xenografts in murine models in vivo [8]. Progesterone was already known to have beneficial effects on the outcome of brain injuries accompanied with cerebral edema and inflammation [9] and known to feature dose-dependent antiproliferative and proapoptotic effects in other tumors including breast, ovarian, and endometrial cancer [10,11]. Although these effects were observed and documented, the background of progesterone 
mediated response in tumor cells is not fully elucidated. The action of progesterone depends on different mechanisms including a slow, genomic mediated response via nuclear progesterone receptors (nPGR) and a fast, nongenomic action, which can be mediated via membrane-associated progesterone receptors (MAPRs) [12-14]. Some effects of progesterone in glioma cells can be mediated via the nuclear receptors but other cannot, suggesting a potential role of the MAPRs. Members of the MAPRs were localized in different regions of the rat brain [15]. Furthermore, it was demonstrated that the sex steroid hormones $17 \beta$-estradiol and progesterone influence the expression of MAPRs in the brain [16]. In neuroendocrinology, it was shown that in the hippocampus the classical nPGR responded differently to estrogen and progesterone supplementation compared to PGRMC1 during the rat estrous cycle [17]. Furthermore, PGRMC1 knockdown in microglia suppressed the progesterone $17 \beta$-estradiol antagonism of neurite outgrowth in female rat brain [18]. In different cells and tissues, it has been reported that PGRMC1 is associated with cell cycle regulation including proproliferative and antiapoptotic effects in response to progesterone [19-22]. Therefore, the close interaction of progesterone mediated effects and PGRMC1 expression, especially in glia cells, is supposed to be a potential target to study the nPGR-independent effects of progesterone on glioma cells and, thereby, PGRMC1 was selected as protein of interest in the present study.

Mediating the responsiveness to progesterone via PGRMC1 was assumed to be partially depending on plasminogen activator inhibitor 1 RNA-binding protein (PAIRBP1), also known as SERPINE1 mRNA-binding protein (SERBP1) $[19,23]$, which was also identified to be expressed in the different regions of the rat brain [15]. PAIRBP1 participates in the antiapoptotic actions of progesterone in spontaneously immortalized granulosa cells, but a recent study identified progesterone binding being independent from its interaction with PAIRBP1 [19]. Based on these results, it is suggested that PAIRBP1 is not a component of the membrane progesterone receptor but instead is an involved downstream component of the signaling pathway leading to protection against apoptosis and was therefore selected to be a further protein of interest in the present study.

Additionally, the MAPR family member PAQR7 (mPR $\alpha)$ has to be investigated in detail as a potential binding partner for PGRMC1 because comparable antiapoptotic progestin actions mediated through these two membrane proteins were identified $[24,25]$. Recent studies demonstrated that progesterone-induced alterations of different genes involved in the antiapoptotic pathways include both PAQR7 and PGRMC1 $[22,26]$ and that PGRMC1 and PAQR7 together with PGRMC2 form a complex within the cytoplasm which seems to be required for P4's action [27]. Progesterone dependent PI3K/Akt/mTOR signaling modulation was observed in glioma cells in vitro although the nPGR was blocked by RU486, an inhibitor of the nPGR, suggesting that the nongenomic action of progesterone via MAPRs has an important role in the progesterone responsiveness of glioma cells [8].

Therefore, the aim of the study was to investigate the effects of different concentrations of progesterone on
PGRMC1, PAIRBP1, and PAQR7 expression in glioma cell spheroids on mRNA and protein levels. Two different cell lines were used to identify potential differences between GBM cells of female (LN-229) and male (U-87 MG) origin. The application of a three-dimensional glioma cell spheroid model was relevant to mimic the natural tumor situation in more detail compared to a monolayer cell culture [28].

\section{Materials and Methods}

2.1. Cell Lines and Cell Culture. The human glioma cell lines LN-229 and U-87 MG were obtained from LGC Promochem (CRL-2611) and Cell Line Service (CLS\# 300367), respectively. The short tandem repeat (STR) analysis performed at the Cell Culture Facility of the Medical University of Graz, Austria, confirmed the cell lines' identity. The cells were maintained in Dulbecco's modified Eagle's medium containing $4.5 \mathrm{~g} / \mathrm{L}$ glucose (DMEM, Sigma) supplemented with $10 \%$ heat-inactivated fetal calf serum (FCS, Sigma) and antibiotic-antimycotic mix (BioSell), hereafter referred to as growth medium, in a humidified atmosphere with $5 \% \mathrm{CO}_{2}$ at $37^{\circ} \mathrm{C}$.

Spheroids were grown by inoculating $2 \times 10^{6}$ cells in nonadherent $90 \mathrm{~mm}$ petri-dishes (Rotilabo ${ }^{\circledR}$ Petrischalen, $\mathrm{ROTH}$ ) in $10 \mathrm{~mL}$ of growth medium in the absence of additional scaffolds and matrices. Clusters of cells were observed 24 hours after seeding. The medium was changed every second day until spheroids reached day 14. Progesterone (Sigma) stimulation at the concentration previously used by Ramaswamy ( $3 \mathrm{ng} / \mathrm{mL}$ or $30 \mathrm{ng} / \mathrm{mL}$ equal to $9.54 \mathrm{nM}$ or $95.4 \mathrm{nM}$ of progesterone) was performed for the last two days of cultivation (D13, D14) with medium exchange every day [29]. Four independent biological replicates per group were prepared and used for further analysis unless otherwise indicated.

Spheroids were harvested by centrifugation at room temperature (1000 rpm for $3 \mathrm{~min}$ ), washed with PBS (Sigma), and either prepared for histological analysis as described below or stored as dry pellet at $-80^{\circ} \mathrm{C}$ until being further processed.

2.2. RT-qPCR. Spheroid pellets were resuspended in $600 \mu \mathrm{L}$ QIAzol lysis reagent (Qiagen, Hilden, Germany) and mechanically homogenized with MagNA Lyser instrument (Roche, Rotkreuz, Switzerland) using $1.2 \mathrm{~mm}$ ceramic beads at $6000 \mathrm{rpm}$ for $20 \mathrm{sec}$. Subsequently, the homogenized samples were chilled on ice and centrifuged $(12000 \times \mathrm{g}$ for $1 \mathrm{~min}$ ) and the cellular RNA was extracted using the Direct-zol RNA Miniprep Kit (Zymo Research, Irvine, USA) following the recommended protocol. All RNA samples were treated with DNase I (Turbo DNA-Free Kit, Ambion, Austin, USA) to remove contaminating DNA. RNA quality control was performed on the Agilent 2100 Bioanalyzer using the RNA Nano 6000 Kit (Agilent Technologies, Santa Clara, USA). The measured RNA integrity numbers ranged from 8.3 to 10 . The RT-qPCR primers for the target gene PAQR7 and the reference gene RPL27 were taken from the literature [30, 31]. Hydrolysis probes were designed for 
the existing primer pairs to increase the target specificity (Supplementary Table 1 in Supplementary Material available online at http://dx.doi.org/10.1155/2016/8065830). Additional RT-qPCR assays were designed for PGRMC1 and PAIRB1 using the PrimerExpress 2.0 software (Life Technologies, Carlsbad, USA). All assays were validated by the generation of standard curves and the calculation of PCR reaction efficiencies using the formula described in Klein [32]. For RT-qPCR, $1 \mu \mathrm{g}$ total RNA was retrotranscribed into cDNA utilizing the High Capacity Reverse Transcription Kit (Life Technologies) according to the manufacturer's instructions. Minus reverse transcription controls (samples in which no RT enzyme was added) were included for all RNAs to monitor the amplification of residual DNA. RT-qPCR reactions were done in $20 \mu \mathrm{L}$ mixes including $12.5 \mathrm{ng}$ cDNA template, $0.2 \mathrm{mM}$ of each dNTP, $3 \mathrm{mM} \mathrm{MgCl}$, 1x buffer B2 (Solis BioDyne, Tartu, Estonia), $300 \mathrm{nM}$ of each primer, $200 \mathrm{nM}$ probe, $50 \mathrm{nM}$ ROX reference dye (Biotium, Hayward, USA), and 1-unit HOT FIREPol DNA polymerase (Solis BioDyne). All samples were analyzed in duplicates on a Viia7 Real-Time PCR System (Life Technologies) using the following temperature profile: initial denaturation at $95^{\circ} \mathrm{C}$ for $10 \mathrm{~min}, 45$ cycles of $95^{\circ} \mathrm{C}$ for $15 \mathrm{sec}$, and $60^{\circ} \mathrm{C}$ for $1 \mathrm{~min}$. The expression stability of RPL27 was assessed with the BestKeeper analysis tool [33]. Target gene expression levels were then normalized to those of the reference gene (RPL27) and relative expression changes were calculated using the comparative $2^{-\Delta \Delta C T}$ method [34].

2.3. RT-PCR. The expression of the nuclear progesterone receptor (nPGR) was investigated by reverse transcription PCR (RT-PCR). Two previously described RT-PCR assays were used to ensure the detection of all known PGR transcript isoforms A-D (accession numbers NM_000926.4, NM_001202474.3, NM_001271161.2, and NM_001271162.1). The first assay named "PGR," by Latil [35], detects the isoforms $\mathrm{A}-\mathrm{C}$, whereas the second RT-PCR "PR-A + B" [36] amplifies A, B, and D (Supplemental Table 1). The reaction mixes for RT-PCR were identical to those of RT-qPCR, except that the probe and ROX reference dye were omitted and replaced with water. The PCR temperature profiles were performed as described in the original papers [35, 36]. PCR products were separated on a $2 \%$ agarose gel, stained with the GelGreen DNA dye (Biotium, Hayward, USA), and visualized under blue light excitation. RNA from T-47D cells was included as a positive control for the PGR RT-PCR. The RPL27 gene was used as internal standard to measure the RNA input quantity.

2.4. Sample Preparation for Immunohistochemical Analysis. Spheroids were resuspended in $1 \mathrm{~mL} 4 \%$ buffered formaldehyde and stored at $4^{\circ} \mathrm{C}$ for 48 hours. The fixed spheroids were centrifuged as described above and the pellet was overlaid with $500 \mu \mathrm{L}$ Histogel $^{\circledR}$ (Richard-Allan Scientific, Microm International, Walldorf, Germany; as specified by the manufacturer). The solidified spheroid pellet was subsequently embedded in Paraplast ${ }^{\circledR}$ (Vogel, Giessen, Germany) by means of an automatic embedding device. Serial sections of $3 \mu \mathrm{m}$ thickness were cut and either stained with hematoxylin and eosin (H\&E) according to Romeis [37] for morphological analyses or mounted on 3aminopropyltriethoxysilane/glutaraldehyde-coated slides for the different immunohistochemical analyses.

2.5. Immunohistochemistry. Endogenous peroxidase activity was blocked by incubation in $0.6 \% \mathrm{H}_{2} \mathrm{O}_{2}$ in methanol for $15 \mathrm{~min}$ at room temperature. A protein block (1.5\% normal goat serum) was used to minimize unspecific binding of the primary antibody. The unlabeled primary antibodies (anti-Ki67, anti-PAIRBP1, anti-PAQR7, and anti-PGRMC1; for sources, pretreatments, and dilutions, see Supplemental Table 2) were detected with the ImmunoVision secondary system (ImmunoVision Technologies, Brisbane, CA, USA) using 3,3' -diaminobenzidine-tetrahydrochloride substrate in Tris- $\mathrm{HCl}$ buffer $\mathrm{pH} 7.4$ and $0.03 \% \mathrm{H}_{2} \mathrm{O}_{2}$ as chromogen. Finally, slides were washed with distilled water, counterstained with haemalum, dehydrated, and mounted by use of xylene-soluble medium (DPX, Fluka, Buchs, Switzerland). For the double immunofluorescent detection of PGRMC1 and PAIRBP1, Alexa Fluor ${ }^{\mathrm{TM}} 488$ and Alexa Fluor $^{\mathrm{TM}} 568$ goat anti-mouse (Molecular Probes, Eugene, OR, USA; dilution $1: 100)$ secondary antibodies were used with the UltraVision Quanto Mouse on Mouse HRP Blocking (Thermo Fisher, TL-060-QHDM) in between the two different antibodies for $30 \mathrm{~min}$ on room temperature. Nuclear counterstaining was performed with 4',6-diamidino-2-phenylindole (Molecular Probes/Life Technologies, Vienna, Austria). Negative controls were performed by substituting the primary antibodies with PBS. Sections for the establishment of the immunohistochemical protocols on canine tissue and sections of T47D tumor cells were kindly provided by the Vetmeduni VetBiobank, VetCore Facility for Research (Vienna, Austria).

Evaluation of the sections was performed using light microscopy (Polyvar, Reichert-Jung, Vienna, Austria) and confocal laser scanning microscopy (Zeiss, LSM 510 Meta, Vienna, Austria).

2.6. Scoring System for Proliferative Activity. Proliferative activity was assessed by nuclear anti-Ki67 staining. The nuclei positive for Ki67 protein were counted in three spheroid cross sections per section by using three different sections and four biological replicates per group, resulting in a total number of 36 spheroid cross sections per group. Proliferative activity was determined as the percentage of Ki67-positive cells of total cell number counted per group (scoring index).

2.7. Western Blot. Frozen spheroids or PBS-washed fresh cells were lysed using ice-cold lysis buffer $(10 \mathrm{mM}$ Tris- $\mathrm{HCl} \mathrm{pH}$ 7.5, $100 \mathrm{mM} \mathrm{NaCl}, 1 \mathrm{mM}$ EDTA, $1 \mathrm{mM}$ EGTA, $1 \%$ Triton X100, 10\% Glycerol, 0.1\% SDS, and 0.5\% Na-deoxycholate) supplemented with $1 \%(\mathrm{v} / \mathrm{v})$ of Protease Inhibitor Cocktail and Phosphatase Inhibitor Cocktail 3 (both from SigmaAldrich) using intensive up-and-down pipetting to promote lysis. Samples were then incubated on ice for $30 \mathrm{~min}$, with occasional vortexing. Afterwards, lysates were pushed through $20 \mathrm{G}$ needle several times to shred the DNA followed 


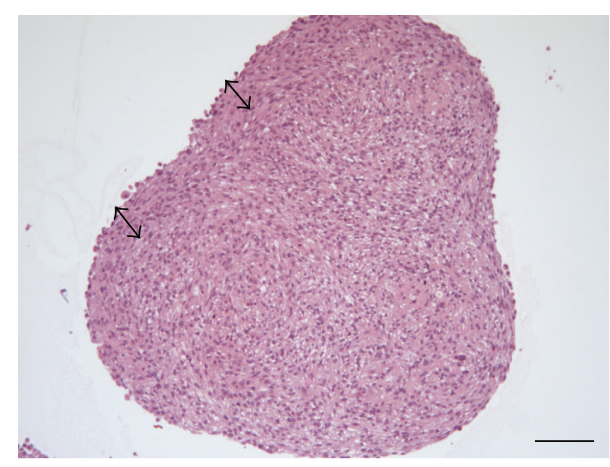

(a)

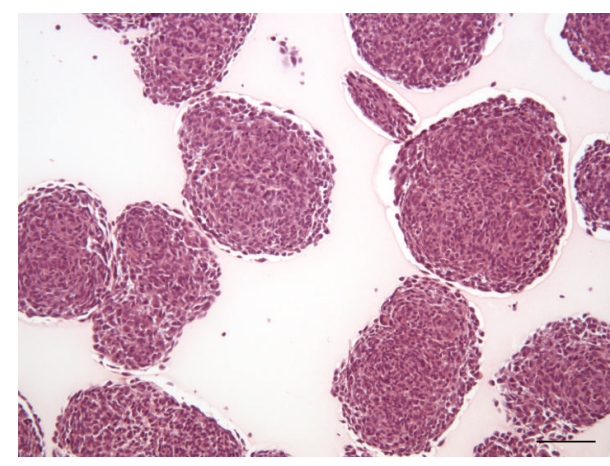

(c)

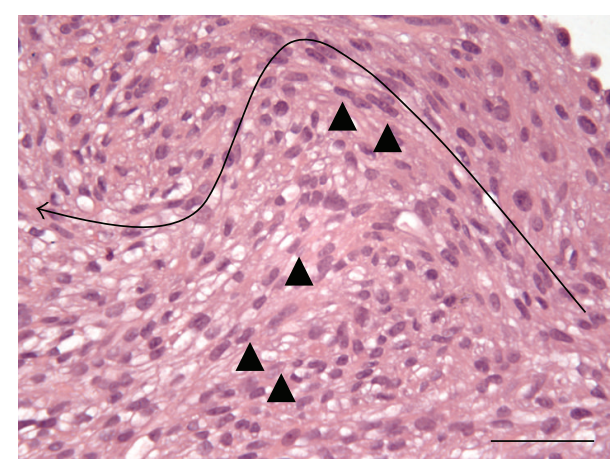

(b)

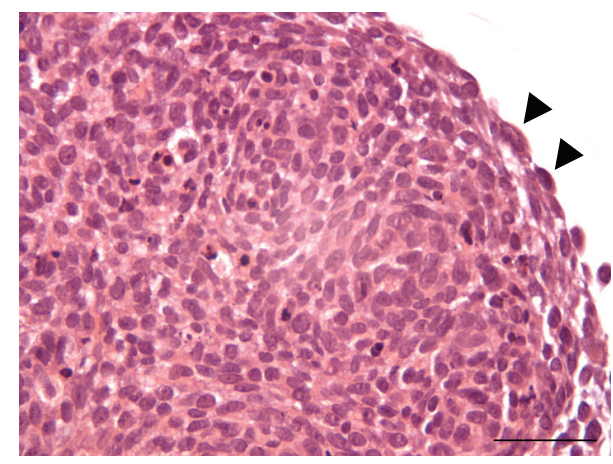

(d)

Figure 1: Histological H\&E stained sections of U-87 MG ((a), (b)) and LN-229 ((c), (d)) glioma cell spheroids grown for 14 days. (a) The arrows indicate the presence of a capsule-like structure in the periphery of the U-87 MG spheroids. (b) Cells in the periphery were orientated partially in a parallel manner and featured elongated spindle-shaped cells with longish nuclei that occasionally grew into the core of the spheroids (black arrow heads) and formed connective tissue like structures. The elongated arrow indicates the route from the periphery to the core. (c) Spheroids grown from LN-229 cells were less dense than U-87 MG spheroids. (d) The spheroid structure was homogenous and only a thin layer of flat cells was observed circumscribing the spheroid (black arrow heads). Scale bars: (a) and (c) $100 \mu \mathrm{m}$, (b) and (d) $50 \mu \mathrm{m}$.

by centrifugation for $15 \mathrm{~min}$ at $4^{\circ} \mathrm{C}$ and $10000 \times \mathrm{g}$. The supernatant fraction was stored at $-80^{\circ} \mathrm{C}$ until further analysis.

Protein extracts $(20 \mu \mathrm{g}$ protein/lane) were separated on $12.5 \%$ (PGRMC1) or 10\% (PAQR7, PAIRBP1) polyacrylamide minigels for SDS-PAGE electrophoresis under reducing conditions and transferred to PVDF membrane (GE Healthcare, UK). Membranes were blocked using Western Blocking Reagent (Roche Diagnostics, Germany; dilution 1:10 in TBST) for two hours at room temperature and probed with the respective primary antibody at $4^{\circ} \mathrm{C}$ overnight. Afterwards, the membranes were incubated with the respective, species-specific secondary antibodies (peroxidase-linked) for $30 \mathrm{~min}$ at room temperature. Proteins were visualized using Amersham Western Blotting Analysis System (GE Healthcare). For negative controls, the membranes were processed in the same way as described above, omitting the respective primary antibody. The primary antibodies for PGRMC1, PAQR7, and PAIRBP1 were the same as indicated in Supplemental Table 2 (respective dilutions of $1: 1000,1: 200$, and 1:2000). The Amersham ECL-anti-mouse IgG peroxidaselinked species-specific whole antibody from sheep (GE Healthcare, cat. number NA931; dilution 1:5000) and Amersham ECL-anti-rabbit IgG peroxidase-linked species-specific whole antibody from donkey (GE Healthcare, cat. number
NA934; dilution 1:5000) were used as secondary antibodies. All antibodies were diluted in Western Blocking Reagent/TBST $(1: 10)$.

Postimmunodetection, films, and membranes (poststained with Coomassie R-250) were scanned with an Image Scanner III (GE Healthcare Life Sciences) and quantified by densitometric analysis using Quantity One software (version 4.4.0, Bio-Rad). Coomassie protein staining was used as a loading control and for normalization.

2.8. Statistical Analysis. Data are presented as means \pm SD. Statistical analysis between comparable groups was performed using unpaired Student's $t$-test [38]. A value of $p<$ 0.05 was considered statistically significant.

\section{Results}

3.1. Spheroid Formation and Characteristics. The morphological analysis revealed differences in spheroid size, with spheroids grown from U-87 MG cells being 2.6-4.2-fold larger than those from LN-229 cells (Figures 1(a) and 1(c)). The U-87 MG spheroids featured a capsule-like outer region which dispatched lanes of elongated cells with longish nuclei into the core composed of two different cell 

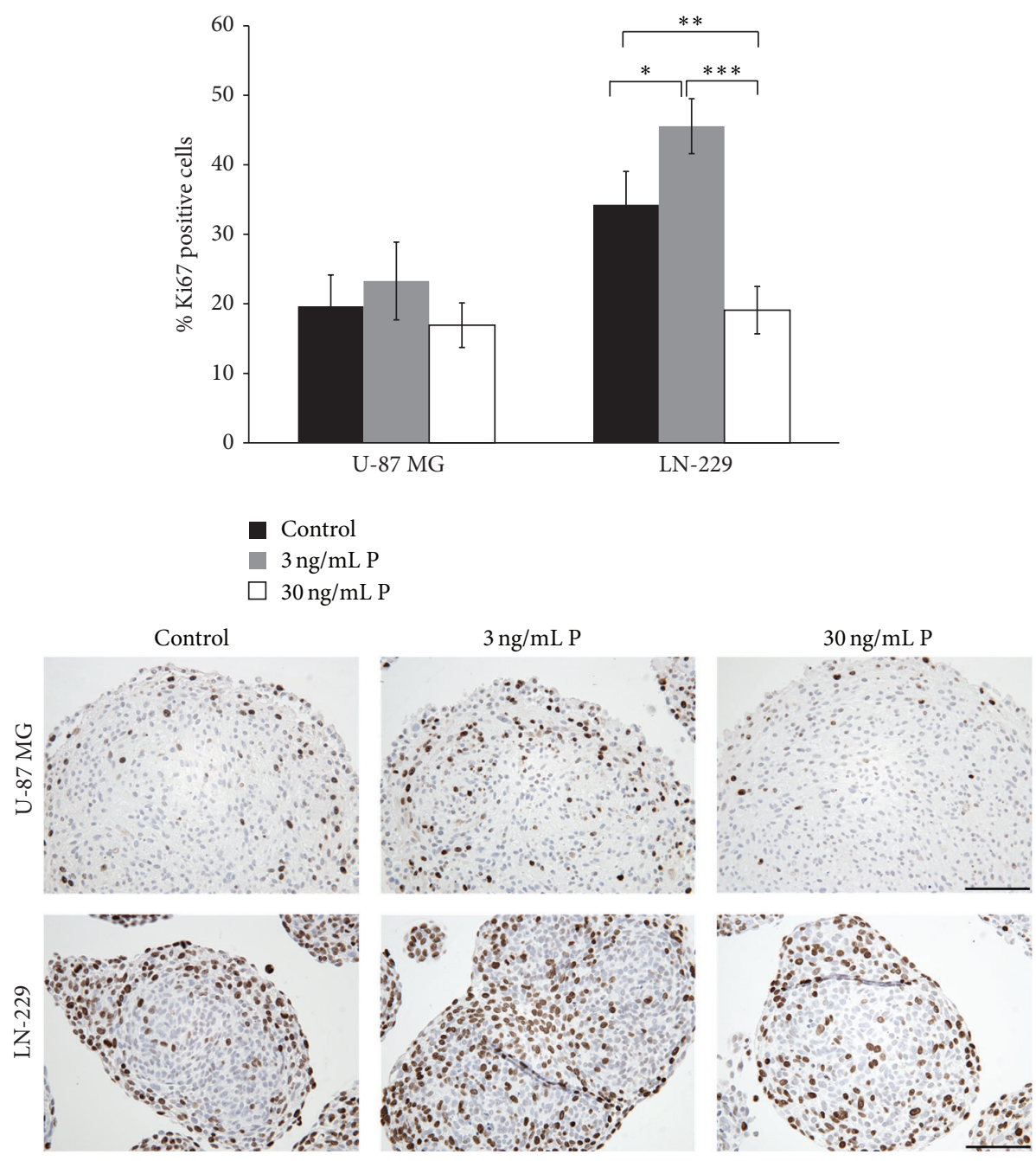

Figure 2: Proliferative activity in U-87 MG and LN-229 glioma spheroids increased by progesterone (P) stimulation using 3 ng/mL P but was reduced by supplementation of $30 \mathrm{ng} / \mathrm{mL}$ P. Proliferative activity was assessed by immunohistochemical detection of the Ki67 protein in the two different glioma spheroid types. Scale bars $100 \mu \mathrm{m}$. Statistical significance $(p<0.05)$ is indicated by an asterisk $\left({ }^{*} p 0.011 ;{ }^{* *} p 0.002\right.$; *** $p$ 0.0001).

types: the elongated and round-to-polygonal cells (Figure 1(b)). The outer region of LN-229 spheroids was composed of one layer of flat cells but a differentiation of a capsule-like region from the core tissue was not observed. The nuclei of the LN-229 cells differ partially in size but not in shape (Figure 1(d)).

\subsection{Effect of Progesterone Treatment on Proliferative Activity.} Proliferative activity of the spheroids of both glioma cell lines increased by stimulation with $3 \mathrm{ng} / \mathrm{mL}$ but decreased as a result of $30 \mathrm{ng} / \mathrm{mL} \mathrm{P}$ supplementation (Figure 2). Even though this trend was observed in both spheroid types, statistically significant differences $(p<0.05)$ were obtained only in LN-229 spheroids. In U-87 MG spheroids' proliferative activity in the control and $30 \mathrm{ng} / \mathrm{mL} \mathrm{P}$ group was mainly restricted to the outer zone of the spheroid, whereas stimulation with $3 \mathrm{ng} / \mathrm{mL}$ increased the number of both peripheral and central cells (Figure 2). In LN-229 spheroids, a distinct concentration of most of the Ki67 positive cells in the spheroid periphery was only observed in the control group, whereas $3 \mathrm{ng} / \mathrm{mL} \mathrm{P}$ stimulated spheroids featured a high number of Ki67 positive cells in both the periphery and the core (Figure 2).

3.3. Effect of Progesterone Treatment on PGRMC1, PAIRBP1, and PAQR7 mRNA Levels. Progesterone treatment of U87 MG spheroids did not cause any significant changes in PGRMC1, PAIRBP1, and PAQR7 mRNA transcript levels compared to untreated spheroids as shown by the RT-qPCR analysis performed on these samples. However, a positive albeit nonsignificant effect of progesterone on PGRMC1 and PAIRBP1 mRNA levels in U-87 MG spheroids was observed. While the PAQR7 transcript levels were unaffected by progesterone in LN-229 spheroids, a negative trend in PAIRBP1 and PGRMC1 mRNA levels was observed with significant decrease $(p<0.05)$ in PGRMC1 transcript amounts in spheroids treated with $30 \mathrm{ng} / \mathrm{mL}$ progesterone (Figure 3). 


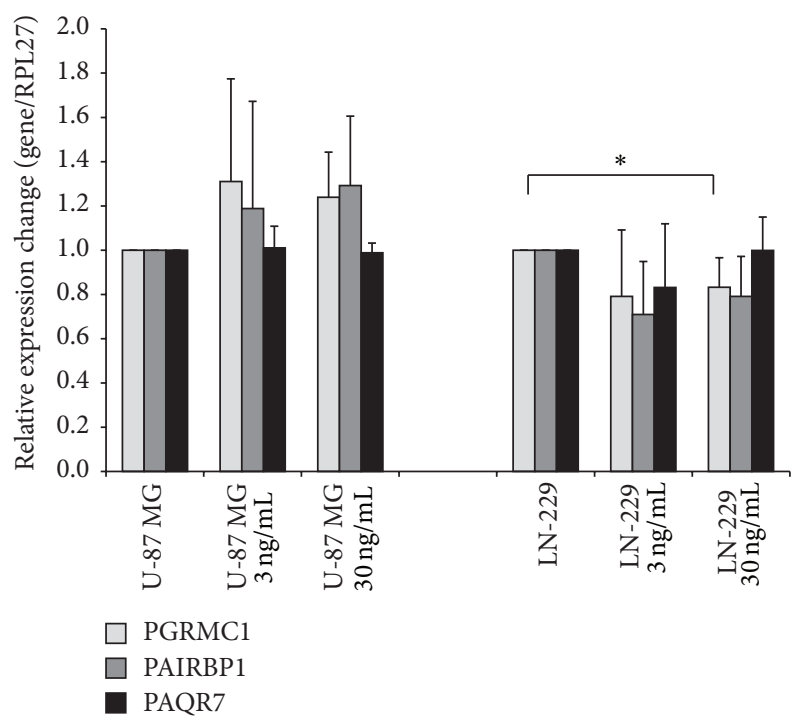

FIgURE 3: RT-qPCR of PGRMC1, PAIRBP1, and PAQR7 transcripts in U-87 MG and LN-229 glioma spheroids stimulated with $3 \mathrm{ng} / \mathrm{mL}$ and $30 \mathrm{ng} / \mathrm{mL}$ progesterone, respectively, for $48 \mathrm{hrs}$. The only significant alteration, decrease in PGRMC1 mRNA level, was observed in $\mathrm{LN}-229$ spheroids treated with $30 \mathrm{ng} / \mathrm{mL}$ of P. Statistical significance $(p<0.05)$ is indicated by an asterisk $\left({ }^{*} p 0.046\right)$. Data are presented as mean $+\mathrm{SD}$ from four independent experiments.

3.4. Effect of Progesterone Treatment on PGRMC1, PAIRBP1, and PAQR7 Protein Levels. In the immunohistochemical analysis, LN-229 and U-87 MG spheroids were investigated for the expression of PGRMC1, PAIRBP1, and PAQR7 protein. Human breast cancer cells (MCF-7) served as positive control for establishing the immunohistochemical staining for PGRMC1, PAIRBP1, and PAQR7 (Supplemental Figure 1). In the LN-229 spheroids, neither the stimulation with $3 \mathrm{ng} / \mathrm{mL} \mathrm{P}$ nor the stimulation with $30 \mathrm{ng} / \mathrm{mL} \mathrm{P}$ induced any visible alterations in the expression of the three proteins of interest (Figure 4). PGRMC1 and PAIRBP1 were homogenously expressed within the spheroids. PAQR7 protein expression was mainly identified in the cells of the spheroid periphery and in single cells distributed all over the spheroid cross section.

Stimulation of U-87 MG spheroids with both 3 and $30 \mathrm{ng} / \mathrm{mL} \mathrm{P}$ resulted in an increase of PGRMCl protein but in decreased levels of PAIRBP1 compared to the control group. In contrast, PAQR7 was unaffected by $\mathrm{P}$ stimulation (Figure 5). PAIRBP1 and PAQR7 protein expression were observed homogenously through the spheroids.

Double immunofluorescent detection of PGRMC1 and PAIRBP1 identified the two proteins to be colocalized in the cells of the spheroids of both glioma cell lines (Figure 6). Stimulation of the spheroids with $\mathrm{P}$ in different concentrations did not affect the colocalization pattern of the two proteins (not shown).

In the next step, LN-229 and U-87 MG spheroids were analyzed for the expression of PGRMC1, PAIRBP1, and PAQR7 proteins by Western blot using the same antibodies as applied in the immunohistochemical analysis. Stimulation of U-87 MG as well as LN-229 spheroids with both 3 and $30 \mathrm{ng} / \mathrm{mL}$ P did not reveal any changes in PGRMC1 $(\sim 27 \mathrm{kDa})$ and PAIRBP1 $(\sim 58 \mathrm{kDa})$ protein expression (Figure 7$)$. However, detected PGRMC1 levels were higher in U-87 MG spheroids while the PAIRBP1 protein was more abundant in LN-229 spheroids. Interestingly, detection of PAQR7 protein provided two signals at $\sim 48 \mathrm{kDa}$ and $\sim 55 \mathrm{kDa}$ in all spheroids tested. Whereas the $\sim 48 \mathrm{kDa}$ protein was predominant in $\mathrm{U}$ 87 MG spheroids, in LN-229 spheroids, the $\sim 55 \mathrm{kDa}$ form displayed a more intense band. In addition, no changes in bands intensities were observed in LN-229 spheroids, irrespective of the progesterone treatment. On the contrary, progesterone stimulation of the U-87 MG spheroids had a positive effect on PAQR7 expression as demonstrated by increasing intensity of both $\sim 48 \mathrm{kDa}$ and $\sim 55 \mathrm{kDa}$ bands as compared to the unstimulated spheroids.

Semiquantitative densitometric evaluation of PGRMC1, PAIRBP1, and PAQR7 proteins based on three independent sets of Western blot analysis revealed no statistically significant $(p<0.05)$ changes in respective protein expression in nonstimulated versus progesterone-stimulated LN229 spheroids. The only statistically significant difference in protein expression was observed for PAIRBP1 expression in nonstimulated versus $3 \mathrm{ng} / \mathrm{mL}$ of P stimulated U-87 MG spheroids (Figure 8). A nonsignificant, positive effect was also observed in U-87 MG spheroids treated with $30 \mathrm{ng} / \mathrm{mL}$ of progesterone.

\subsection{Analysis of Nuclear Progesterone Receptor Expression.}

The expression of the nuclear progesterone receptor was investigated by RT-PCR detecting all known nPGR transcript isoforms A-D $[35,36]$. The U-87 MG and LN-229 spheroids, both nonstimulated and progesterone-stimulated, were negative for nPGR transcripts (Supplemental Figures 2(a) and 2(b)). The accuracy of the RT-PCR setup as well as the quality of the isolated RNA of all samples was proven by the presence of nPGR signal in the positive control cells (T47D) and signal corresponding to RPL27 expression in all samples tested (Supplemental Figures 2(a), 2(b), and 2(c)). Immunohistochemical detection of nPGR was performed on the corresponding samples as RT-PCR and revealed the absence of nPGR protein expression in both glioma cell lines but detected positive signals in the nuclei of T-47D cells (Supplemental Figure 3).

\section{Discussion}

Although the exact mechanism is not fully elucidated, progesterone is known to have dose-dependent antiproliferative and proapoptotic effects in several tumor types, including neuroblastoma and glioblastoma $[8,39]$. To that end, proliferative activity of the U-87 MG as well as LN-229 spheroids was evaluated in the presence and absence of progesterone stimulation. As measured by the Ki67 labelling index, proliferation was increased by stimulation with low concentration of progesterone $(3 \mathrm{ng} / \mathrm{mL})$ but decreased at high progesterone concentration $(30 \mathrm{ng} / \mathrm{mL})$. Although present in spheroids derived from both glioma cell lines, this effect was stronger 

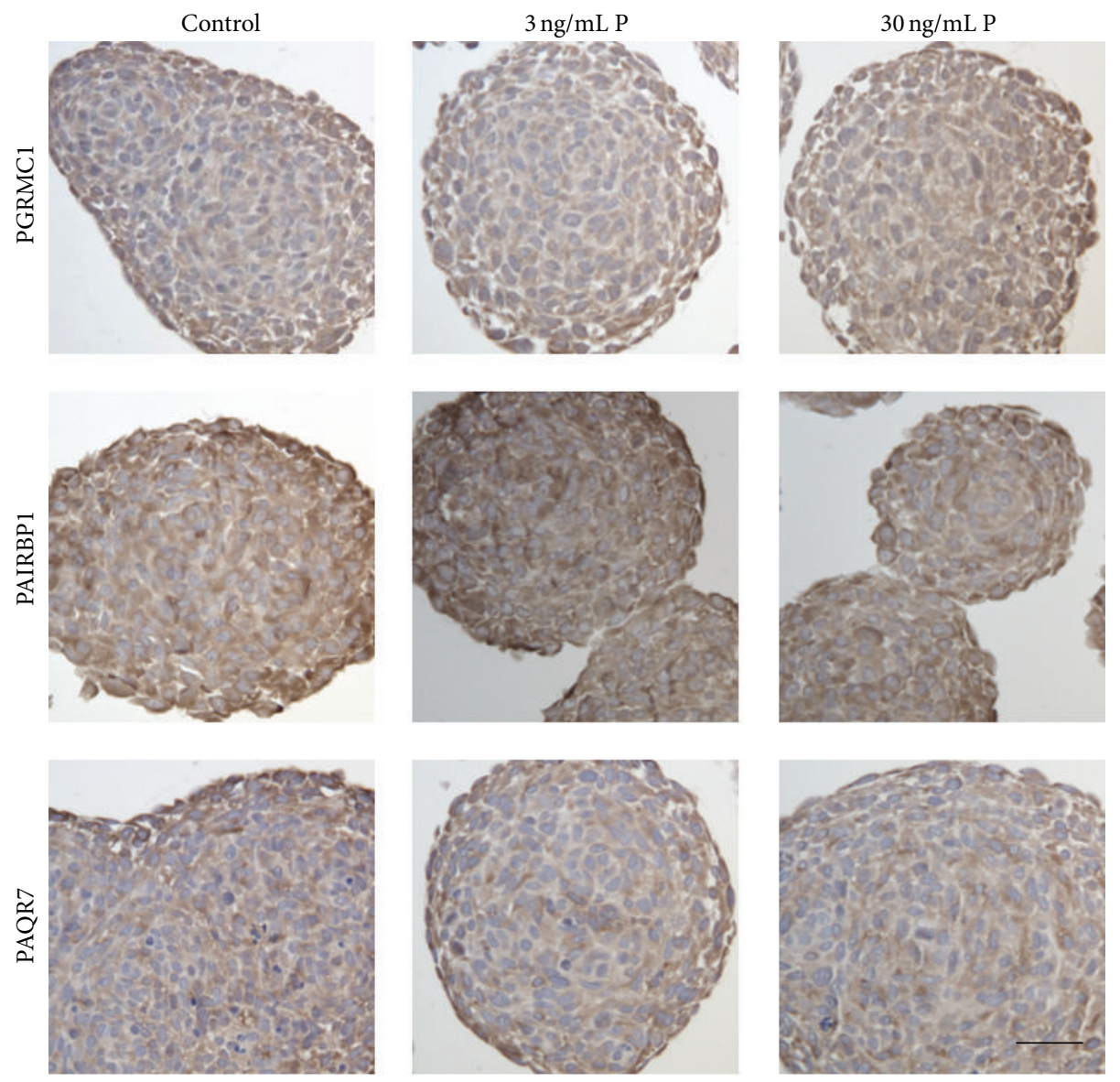

FIGURE 4: Immunohistochemical detection of PGRMC1, PAIRBP1, and PAQR7 proteins in LN-229 glioma spheroids stimulated with 3 ng/mL and $30 \mathrm{ng} / \mathrm{mL}$ progesterone, respectively, for $48 \mathrm{hrs}$. P supplementation did not induce any alterations in the spheroids compared to the unstimulated control. Scale bar $25 \mu \mathrm{m}$.

and statistically relevant only in LN-229 spheroids. Hence, our results further supported the existence of a dual hormetic effect of progesterone on glioma cell proliferation in vitro recently described by Atif et al. [40], irrespective of the technique of cell cultivation. The distribution of anti-Ki67 positive cells determined via immunohistochemistry was divergent in the two different glioma spheroid types. In the U-87 MG spheroids positive cells were counted in the periphery and an increased number of proliferative active cells were determined in the core of these spheroids after stimulation with $3 \mathrm{ng} / \mathrm{mL}$ P. In contrast, in LN-229 spheroids, anti-Ki67 positive cells were mainly located in the periphery of the spheroids. The peripheral concentration of proliferative active cells in spheroids was also reported in other spheroid types constructed from a variety of different cell types [41, 42].

The proposed progesterone action includes the genomic mediated response via nuclear progesterone receptors and the nongenomic action, which can be mediated via membraneassociated progesterone receptors. Nuclear PGR expression in human clinical astrocytoma samples was demonstrated by Khalid [43], in which 31 out of 33 glioblastomas were positive for nPGR. Moreover, nPGR positive astrocytomas had a higher Ki67 labelling index than nPGR negative tumors. It is noteworthy that, despite discrepant literature data [44], the U-87 MG as well as LN-229 spheroids in our study were found negative for $\mathrm{nPGR}$ expression on both the mRNA and protein level as determined by RT-PCR and immunohistochemistry (Supplemental Figures 2 and 3). This discrepancy might result from the different ways of cell culture, because it is well documented that the same cell line cultured in 3D cell culture models differs in gene expression profiles compared to the same cells grown in monolayer cell cultures [42, 45]. Alternatively, it can also be speculated that in different laboratories different types of U-87 MG are cultured. It is well known that cell lines which are commonly used and wide spread sometimes are contaminated with other cell types or change their pheno- and genotype over time and passaging [46]. To ensure the identity of cells used in our study, the STR analysis using Power Plex ${ }^{\circledR} 16$ system (Promega) was performed by an independent research/service facility (CellBank Graz, Austria). As expected, results of this analysis clearly confirmed identity of U-87 MG and LN-229 cells (Supplemental Figure 4) [47]. Thus, we conclude that the used U-87 MG and LN-229 cells are negative for nPGR. As a consequence of this observation, we further speculate that the progesterone effect on the cellular proliferation was 

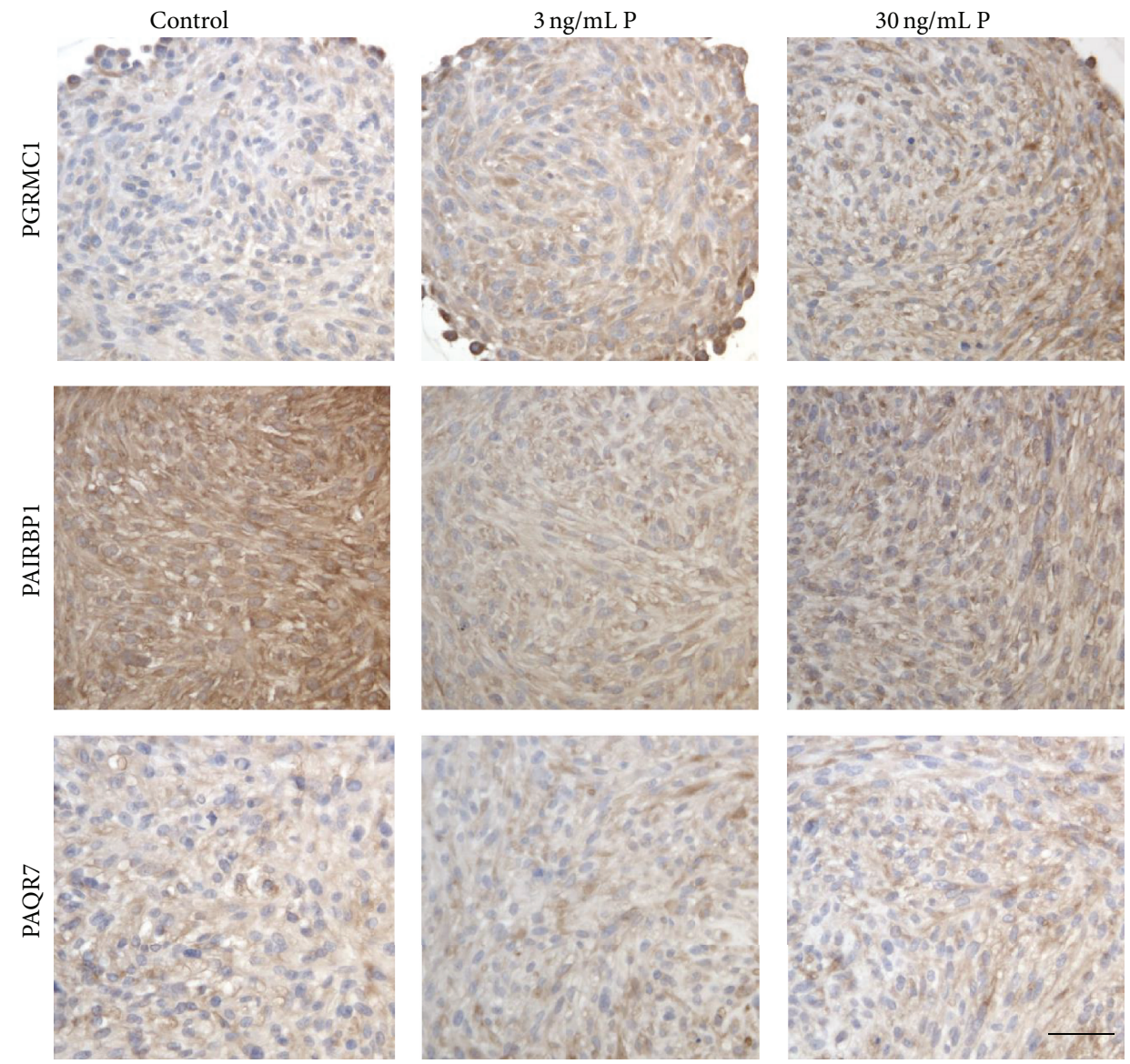

FIGURE 5: Identification of PGRMC1, PAIRBP1, and PAQR7 protein expression in U-87 MG glioma cell spheroids after 48 hrs progesterone stimulation by means of immunohistochemistry. PGRMC1 protein expression slightly increased through P stimulation, whereas PAIRBP1 expression was decreased. PAQR7 protein expression was unaffected by P supplementation. Scale bar $25 \mu \mathrm{m}$.

mediated via membrane-associated progesterone receptors. Therefore, we have documented the existence of membraneassociated progesterone receptors PAQR7 and PGRMC1 and of the proposed PGRMC1-downstream component PAIRBP1 in these spheroids in response to progesterone treatment.

In a Western blot analysis, the PGRMC1 protein is predominantly detected as a $\sim 27 \mathrm{kDa}$ band corresponding to a cytoplasmic form, whereas usually less abundant, higher molecular weight bands $(\sim 56 \mathrm{kDa}$ and $\sim 75 \mathrm{kDa})$ correspond to nuclear localization [22, 48]. Immunohistochemical studies located PGRMC1 in the extracellular surface of the plasma membrane, intracellular membranes, cytoplasm, and nucleus $[48,49]$. Western blot analysis of spheroid samples revealed, consistent with Peluso's observations, the presence of a $27 \mathrm{kDa}$ band corresponding to PGRMC1 as the only positive signal detected through the samples [48]. This signal was constant within the spheroid type and the intensity was independent of progesterone treatment. These data are in accordance with the results of immunohistochemical analysis revealing cytoplasmic PGRMC1 as the predominant form detected in the spheroids (Figure 6). However, in addition to cytoplasmic distribution, a number of scattered signals in the nuclei were identified in both U-87 MG and LN-229 spheroids. We can only anticipate that this nuclear PGRMC1 represents a phosphorylated form of PGRMC1, as it has been described in HeLa cells [50].

The PAIRBP1 protein, also known as SERBP1, is differently expressed throughout the human body with low PAIRBP1 expression levels in the brain [51]. Although the exact mechanism of action is not clear, PAIRBP1 has been implicated in tumorigenicity and resistance to anticancer drugs [52, 53]. In ovarian carcinoma, overexpression of PAIRBP1 was associated with higher tumor grading (Grade III versus Grades II and I tumors), while high metastatic potential was linked to PAIRBP1 overexpression in nonsmall cell lung cancer cells $[54,55]$. The PAIRBP1 gene is one out of ten most influential genes for glioblastoma multiforme development [56]. Despite low expression levels in brain tissue observed by Serce, PAIRBP1 upregulation has been found in GBM [51, 56]. Indeed, U-87 MG and LN229 spheroids were positive for PAIRBP1 expression, at both mRNA and protein level. Similar to PGRMC1, a statistically nonsignificant positive effect of progesterone on PAIRBP1 mRNA expression was observed in U-87 MG spheroids. However, a marginal but rather negative effect was detected in LN-229 spheroids. Surprisingly, Western blot analysis 

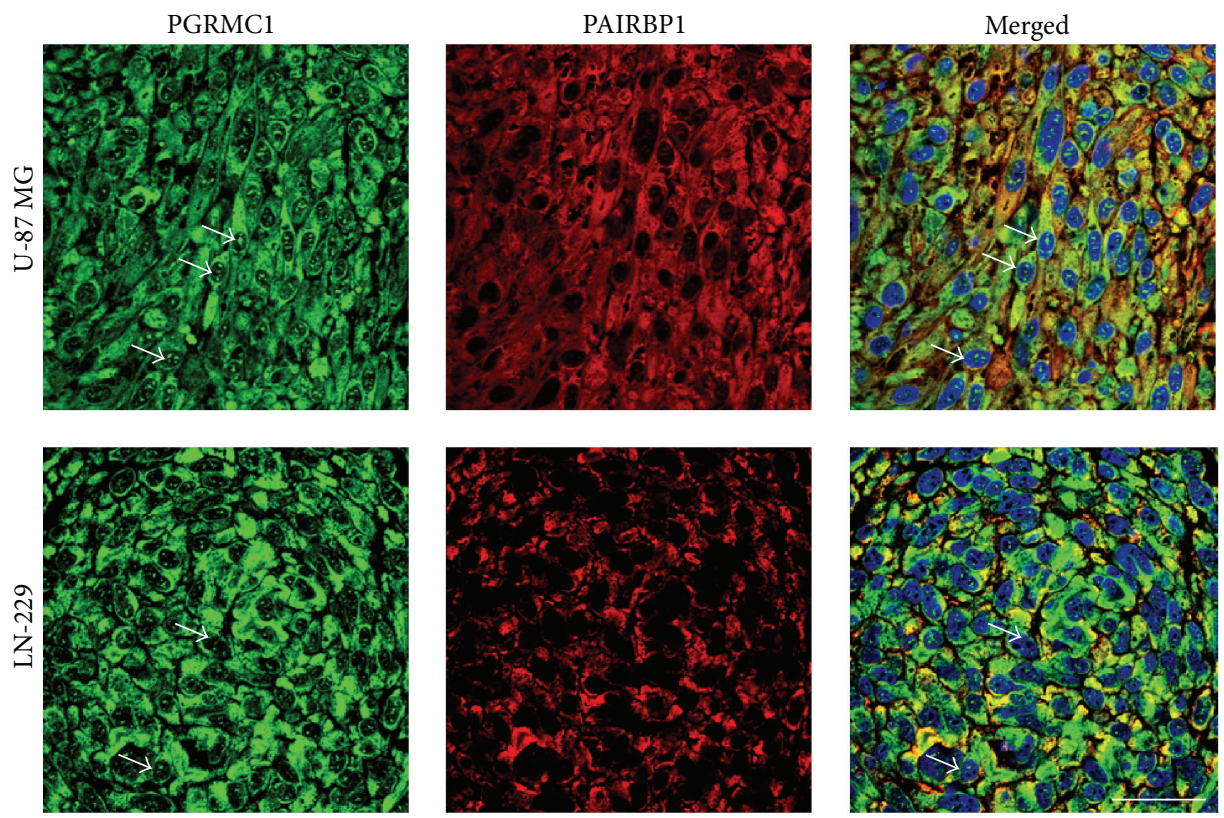

FIGURE 6: Demonstration of the colocalization of PGRMC1 (green) and PAIRBP1 (red) proteins in U-87 MG and LN-229 glioma cell spheroids by means of double-immunofluorescence. Regions of colocalization are demonstrated by yellow color indicating merged red and green signals. In both cell lines, nuclear PGRMC1 staining (white arrows) was observed. Nuclear counterstaining was performed with $4^{\prime}$,6-diamidino-2phenylindole (blue). Scale bar $20 \mu \mathrm{m}$.

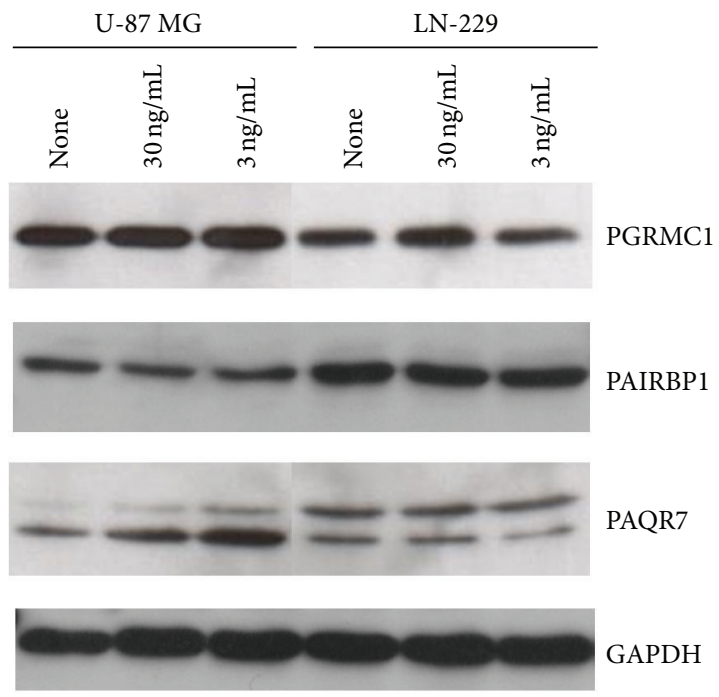

FIGURE 7: Western blot detection of PGRMC1, PAIRBP1, and PAQR7 protein expression in U-87 MG and LN-229 glioma cell spheroids after 48 hrs progesterone (P) stimulation. Whereas PGRMC1 and PAIRBP1 protein detection revealed the expected band at about $27 \mathrm{kDa}$ and $58 \mathrm{kDa}$, respectively, two bands migrating at about $48 \mathrm{kDa}$ and $55 \mathrm{kDa}$ were detected using the PAQR7 antibody. A representative Western blot is shown.

revealed a stronger signal in LN-229 spheroids, with no significant effect of progesterone on PAIRBP1 expression in LN229 spheroids. However, the semiquantitative densitometric

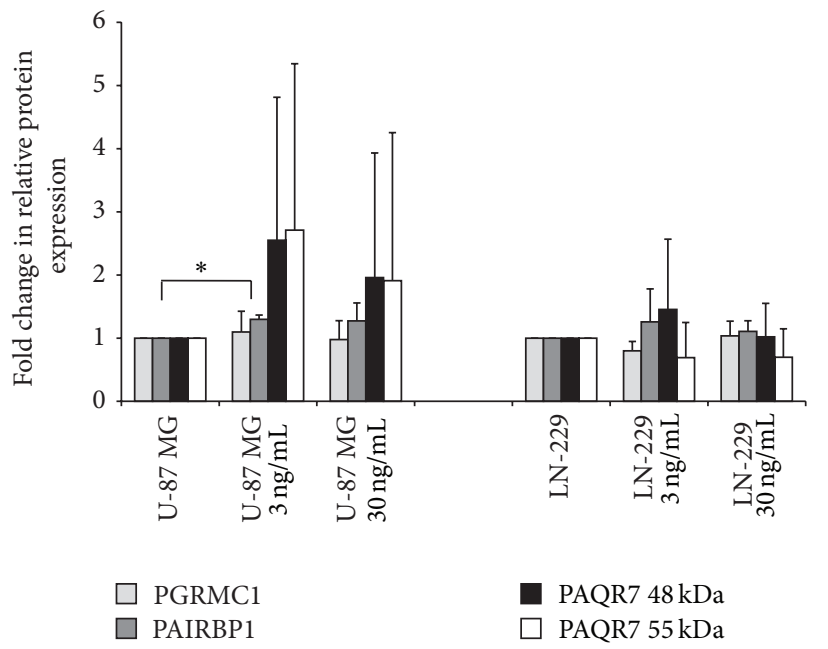

FIGURE 8: Densitometric analysis of protein expression detected by Western blot. Shown is a fold change in relation to protein amount upon progesterone stimulation. Data are based on protein amount normalized onto the total protein staining in the respective lane. Statistical significance $(p<0.05)$ is indicated by an asterisk $\left({ }^{*} p\right.$ 0.018). Data are presented as mean + SD from three independent experiments.

analysis of the respective band (normalized onto the total protein amount loaded per lane) in Western blot revealed a significant increase in PAIRBP1 expression in U-87 MG spheroids treated with low $\mathrm{P}$ concentration. Progesterone stimulation did not have an effect on the PAIRBP1 protein 
localization in both cell lines determined by immunohistochemistry. Thus, no evidence of progesterone-induced cellular stress was observed, as the PAIRBP1 translocates to nuclear-dominant localization upon stress conditions [57].

Recently, PAQR7 expression has been described in human astrocytoma cell lines U-87 and U-251 [58]. In accordance with this observation, PAQR7 expression was also detected in U-87 MG and LN-229 spheroids at mRNA and protein levels. Surprisingly, using polyclonal rabbit antiPAQR7 antibody from Sigma, PAQR7 was detected as a doublet signal of $\sim 48$ and $55 \mathrm{kDa}$ in both U-87 MG and LN-229 spheroids, which was not previously observed by Valadez-Cosmes, using a different PAQR7 antibody [58]. In addition, a positive effect of progesterone on PAQR7 expression was observed in U-87 MG spheroids, while this effect was absent in those derived from LN-229 cells.

\section{Conclusion}

In glioma spheroids grown from U-87 MG and LN-229 cells, membrane-associated progesterone receptors were identified to be involved in the responsiveness of these microtumors in vitro to progesterone in a dose-dependent way. As both cell lines were negative for nPGR on protein and mRNA level, we assume that the investigated membrane-associated progesterone receptors are relevant for both the genomic and the nongenomic action of progesterone in the investigated glioma cells. Thus, further investigation of these membraneassociated receptors is necessary to elucidate the function of progesterone action in glioblastoma growth and development and also to reveal their potential for novel therapeutic strategies.

\begin{tabular}{|c|c|}
\hline \multicolumn{2}{|c|}{ Abbreviations } \\
\hline bp: & Base pair \\
\hline DMEM: & Dulbecco's modified Eagle's medium \\
\hline GAPDH: & $\begin{array}{l}\text { Glyceraldehyde-3-phosphate } \\
\text { dehydrogenase }\end{array}$ \\
\hline GBM: & Glioblastoma multiforme \\
\hline H\&E: & Hematoxylin and eosin stain \\
\hline kDa: & Kilodalton \\
\hline MAPR: & $\begin{array}{l}\text { Membrane-associated progesterone } \\
\text { receptors }\end{array}$ \\
\hline nPGR: & Nuclear progesterone receptors \\
\hline & Progesterone \\
\hline PAIRBP1: & $\begin{array}{l}\text { Plasminogen activator inhibitor } 1 \\
\text { RNA-binding protein }\end{array}$ \\
\hline PAQR7: & Progestin and adipoQ receptor 7 \\
\hline PCR: & Polymerase chain reaction \\
\hline PGRMC1: & $\begin{array}{l}\text { Progesterone receptor membrane } \\
\text { component } 1\end{array}$ \\
\hline RT-PCR: & Reverse transcription PCR \\
\hline ERBP1: & SERPINE1 mRNA-binding protein \\
\hline
\end{tabular}

\section{Competing Interests}

The authors declare that they have no competing interests.

\section{Acknowledgments}

The authors are grateful to Mrs. Claudia Höchsmann, Irina Kolarov, Brigitte Machac, and Anne Flemming for the excellent technical assistance.

\section{References}

[1] C. Adamson, O. O. Kanu, A. I. Mehta et al., "Glioblastoma multiforme: a review of where we have been and where we are going," Expert Opinion on Investigational Drugs, vol. 18, no. 8, pp. 1061-1083, 2009.

[2] O. O. Kanu, A. Mehta, C. Di et al., "Glioblastoma multiforme: a review of therapeutic targets," Expert Opinion on Therapeutic Targets, vol. 13, no. 6, pp. 701-718, 2009.

[3] P. Navarria, G. L. Banna, E. Aimar, B. Ferrari, A. Bertuzzi et al., "Radiotherapy (RT) plus concomitant and adjuvant temozolomide (TMZ) for high-grade gliomas (HGGS) other than gliobastoma multiforme (GBM): preliminary results," Annals of Oncology, vol. 16, article 63, 2005.

[4] R. J. Komotar, D. A. Wilson, and E. S. Connolly, "Radiotherapy plus concomitant and adjuvant temozolomide for glioblastoma," Neurosurgery, vol. 57, no. 1, pp. N7-N8, 2005.

[5] A. Cowppli-Bony, G. Bouvier, M. Rué et al., "Brain tumors and hormonal factors: review of the epidemiological literature," Cancer Causes \& Control, vol. 22, no. 5, pp. 697-714, 2011.

[6] Z.-Y. Qi, C. Shao, X. Zhang, G.-Z. Hui, and Z. Wang, "Exogenous and endogenous hormones in relation to glioma in women: a meta-analysis of 11 case-control studies," PLOS ONE, vol. 8, no. 7, article e68695, 2013.

[7] G. C. Kabat, Y. Park, A. R. Hollenbeck, A. Schatzkin, and T. E. Rohan, "Reproductive factors and exogenous hormone use and risk of adult glioma in women in the NIH-AARP Diet and Health Study," International Journal of Cancer, vol. 128, no. 4, pp. 944-950, 2011.

[8] F. Atif, S. Yousuf, and D. G. Stein, "Anti-tumor effects of progesterone in human glioblastoma multiforme: role of PI3K/Akt/mTOR signaling," Journal of Steroid Biochemistry and Molecular Biology, vol. 146, pp. 62-73, 2015.

[9] R. Guennoun, F. Labombarda, M. C. Gonzalez Deniselle, P. Liere, A. F. De Nicola, and M. Schumacher, "Progesterone and allopregnanolone in the central nervous system: response to injury and implication for neuroprotection," Journal of Steroid Biochemistry and Molecular Biology, vol. 146, pp. 48-61, 2015.

[10] M. Grott, S. Karakaya, F. Mayer et al., "Progesterone and estrogen prevent cisplatin-induced apoptosis of lung cancer cells," Anticancer Research, vol. 33, no. 3, pp. 791-800, 2013.

[11] L. Rajkumar, F. S. Kittrell, R. C. Guzman, P. H. Brown, S. Nandi, and D. Medina, "Hormone-induced protection of mammary tumorigenesis in genetically engineered mouse models," Breast Cancer Research, vol. 9, no. 1, article R12, 2007.

[12] J. D. Graham and C. L. Clarke, "Expression and transcriptional activity of progesterone receptor A and progesterone receptor B in mammalian cells," Breast Cancer Research, vol. 4, no. 5, pp. 187-190, 2002.

[13] B. Gellersen, M. S. Fernandes, and J. J. Brosens, "Non-genomic progesterone actions in female reproduction," Human Reproduction Update, vol. 15, no. 1, pp. 119-138, 2009.

[14] M. A. Cahill, "Progesterone receptor membrane component 1: an integrative review," Journal of Steroid Biochemistry and Molecular Biology, vol. 105, no. 1-5, pp. 16-36, 2007. 
[15] K. A. Intlekofer and S. L. Petersen, "Distribution of mRNAs encoding classical progestin receptor, progesterone membrane components 1 and 2, serpine mRNA binding protein 1 , and progestin and ADIPOQ receptor family members 7 and 8 in rat forebrain," Neuroscience, vol. 172, pp. 55-65, 2011.

[16] K. A. Intlekofer and S. L. Petersen, "17 $\beta$-estradiol and progesterone regulate multiple progestin signaling molecules in the anteroventral periventricular nucleus, ventromedial nucleus and sexually dimorphic nucleus of the preoptic area in female rats," Neuroscience, vol. 176, pp. 86-92, 2011.

[17] N. Bali, T. E. Morgan, and C. E. Finch, "Pgrmcl: new roles in the microglial mediation of progesterone-antagonism of estradioldependent neurite sprouting and in microglial activation," Frontiers in Neuroscience, vol. 7, article 157, 2013.

[18] N. Bali, J. M. Arimoto, T. E. Morgan, and C. E. Finch, "Progesterone antagonism of neurite outgrowth depends on microglial activation via Pgrmc1/S2R," Endocrinology, vol. 154, no. 7, pp. 2468-2480, 2013.

[19] J. J. Peluso, A. Yuan, X. Liu, and V. Lodde, "Plasminogen activator inhibitor 1 rna-binding protein interacts with progesterone receptor membrane component 1 to regulate progesterone's ability to maintain the viability of spontaneously immortalized granulosa cells and rat granulosa cells," Biology of Reproduction, vol. 88, no. 1, article 20, 2013.

[20] H. Neubauer, Y. Yang, H. Seeger et al., "The presence of a membrane-bound progesterone receptor sensitizes the estradiol-induced effect on the proliferation of human breast cancer cells," Menopause, vol. 18, no. 8, pp. 845-850, 2011.

[21] A. M. Luciano, V. Lodde, F. Franciosi, F. Ceciliani, and J. J. Peluso, "Progesterone receptor membrane component 1 expression and putative function in bovine oocyte maturation, fertilization, and early embryonic development," Reproduction, vol. 140, no. 5, pp. 663-672, 2010.

[22] J. J. Peluso, X. Liu, A. Gawkowska, V. Lodde, and C. A. Wu, "Progesterone inhibits apoptosis in part by PGRMC1-regulated gene expression," Molecular and Cellular Endocrinology, vol. 320, no. 1-2, pp. 153-161, 2010.

[23] L. Zhang, Y. Kanda, D. J. Roberts et al., "Expression of progesterone receptor membrane component 1 and its partner serpine 1 mRNA binding protein in uterine and placental tissues of the mouse and human," Molecular and Cellular Endocrinology, vol. 287, no. 1-2, pp. 81-89, 2008.

[24] P. Thomas, Y. Pang, and J. Dong, "Enhancement of cell surface expression and receptor functions of membrane progestin receptor $\alpha(\mathrm{mPR} \alpha)$ by progesterone receptor membrane component 1 (PGRMC1): evidence for a role of PGRMC1 as an adaptor protein for steroid receptors," Endocrinology, vol. 155, no. 3, pp. 1107-1119, 2014.

[25] P. Thomas and Y. Pang, "Membrane progesterone receptors: evidence for neuroprotective, neurosteroid signaling and neuroendocrine functions in neuronal cells," Neuroendocrinology, vol. 96, no. 2, pp. 162-171, 2012.

[26] G. E. Dressing, R. Alyea, Y. Pang, and P. Thomas, "Membrane progesterone receptors ( $\mathrm{mPRs}$ ) mediate progestin induced antimorbidity in breast cancer cells and are expressed in human breast tumors," Hormones and Cancer, vol. 3, no. 3, pp. 101-112, 2012.

[27] C. Sueldo, X. Liu, and J. J. Peluso, "Progestin and adipoQ receptor 7, progesterone membrane receptor component 1 (PGRMC1), and PGRMC2 and their role in regulating progesterone's ability to suppress human granulosa/luteal cells from entering into the cell cycle," Biology of Reproduction, vol. 93, no. 3, article 63, 2015.

[28] I. Levinger, Y. Ventura, and R. Vago, "Life is three dimensionalas in vitro cancer cultures should be," Advances in Cancer Research, vol. 121, pp. 383-414, 2014.

[29] R. Ramaswamy, K. Ashton, R. Lea et al., "Study of effectiveness of mifepristone for glioma cell line growth suppression," British Journal of Neurosurgery, vol. 26, no. 3, pp. 336-339, 2012.

[30] N. J. Charles, P. Thomas, and C. A. Lange, "Expression of membrane progesterone receptors (mPR/PAQR) in ovarian cancer cells: implications for progesterone-induced signaling events," Hormones \& Cancer, vol. 1, no. 4, pp. 167-176, 2010.

[31] B. Lallemant, A. Evrard, C. Combescure et al., "Reference gene selection for head and neck squamous cell carcinoma gene expression studies," BMC Molecular Biology, vol. 10, article 78, 2009.

[32] D. Klein, P. Janda, R. Steinborn, M. Müller, B. Salmons, and W. H. Günzburg, "Proviral load determination of different feline immunodeficiency virus isolates using real-time polymerase chain reaction: influence of mismatches on quantification," Electrophoresis, vol. 20, no. 2, pp. 291-299, 1999.

[33] M. W. Pfaffl, A. Tichopad, C. Prgomet, and T. P. Neuvians, "Determination of stable housekeeping genes, differentially regulated target genes and sample integrity: BestKeeper-Excelbased tool using pair-wise correlations," Biotechnology Letters, vol. 26, no. 6, pp. 509-515, 2004.

[34] K. J. Livak and T. D. Schmittgen, "Analysis of relative gene expression data using real-time quantitative PCR and the $2^{-\Delta \Delta C_{\mathrm{T}}}$ method," Methods, vol. 25, no. 4, pp. 402-408, 2001.

[35] A. Latil, I. Bièche, D. Vidaud et al., "Evaluation of androgen, estrogen (ER $\alpha$ and $\mathrm{ER} \beta)$, and progesterone receptor expression in human prostate cancer by real-time quantitative reverse transcription-polymerase chain reaction assays," Cancer Research, vol. 61, no. 5, pp. 1919-1926, 2001.

[36] C. M. Luetjens, A. Didolkar, S. Kliesch et al., "Tissue expression of the nuclear progesterone receptor in male non-human primates and men," Journal of Endocrinology, vol. 189, no. 3, pp. 529-539, 2006.

[37] W. U. Mulisch Maria, Ed., Romeis Mikroskopische Technik, Spektrum Akademischer, Heidelberg, Germany, Imprint Springer, 18th edition, 2010.

[38] http://www.physics.csbsju.edu/stats/t-test_bulk_form.html.

[39] F. Atif, I. Sayeed, S. Yousuf et al., "Progesterone inhibits the growth of human neuroblastoma: in vitro and in vivo evidence," Molecular Medicine, vol. 17, no. 9-10, pp. 1084-1094, 2011.

[40] F. Atif, N. R. Patel, S. Yousuf, and D. G. Stein, “The synergistic effect of combination progesterone and temozolomide on human glioblastoma cells," PLoS ONE, vol. 10, no. 6, Article ID e0131441, 2015.

[41] K. E. A. LaRue, M. Khalil, and J. P. Freyer, "Microenvironmental regulation of proliferation in multicellular spheroids is mediated through differential expression of cyclin-dependent kinase inhibitors," Cancer Research, vol. 64, no. 5, pp. 1621-1631, 2004.

[42] S. Breslin and L. O’Driscoll, "Three-dimensional cell culture: the missing link in drug discovery," Drug Discovery Today, vol. 18, no. 5-6, pp. 240-249, 2013.

[43] H. Khalid, S. Shibata, M. Kishikawa, A. Yasunaga, M. Iseki, and T. Hiura, "Immunohistochemical analysis of progesterone receptor and Ki-67 labeling index in astrocytic tumors," Cancer, vol. 80, no. 11, pp. 2133-2140, 1997. 
[44] A. González-Arenas, M. Á. Peña-Ortiz, V. Hansberg-Pastor et al., "PKC $\alpha$ and PKC $\delta$ activation regulates transcriptional activity and degradation of progesterone receptor in human astrocytoma cells," Endocrinology, vol. 156, no. 3, pp. 1010-1022, 2015.

[45] D. K. Mishra, C. J. Creighton, Y. Zhang, D. L. Gibbons, J. M. Kurie, and M. P. Kim, "Gene expression profile of A549 cells from tissue of $4 \mathrm{D}$ model predicts poor prognosis in lung cancer patients," International Journal of Cancer, vol. 134, no. 4, pp. 789-798, 2014.

[46] S. J. O'Brien, "Cell culture forensics," Proceedings of the National Academy of Sciences of the United States of America, vol. 98, no. 14, pp. 7656-7658, 2001.

[47] P. Bady, A.-C. Diserens, V. Castella et al., "DNA fingerprinting of glioma cell lines and considerations on similarity measurements," Neuro-Oncology, vol. 14, no. 6, pp. 701-711, 2012.

[48] J. J. Peluso, J. DeCerbo, and V. Lodde, "Evidence for a genomic mechanism of action for progesterone receptor membrane component-1," Steroids, vol. 77, no. 10, pp. 1007-1012, 2012.

[49] J. J. Peluso, A. Pappalardo, R. Losel, and M. Wehling, "Progesterone membrane receptor component 1 expression in the immature rat ovary and its role in mediating progesterone's antiapoptotic action," Endocrinology, vol. 147, no. 6, pp. 31333140, 2006.

[50] S. A. Beausoleil, M. Jedrychowski, D. Schwartz et al., "Largescale characterization of HeLa cell nuclear phosphoproteins," Proceedings of the National Academy of Sciences of the United States of America, vol. 101, no. 33, pp. 12130-12135, 2004.

[51] N. B. Serce, A. Boesl, I. Klaman et al., "Overexpression of SERBP1 (Plasminogen activator inhibitor 1 RNA binding protein) in human breast cancer is correlated with favourable prognosis," BMC Cancer, vol. 12, article 597, 2012.

[52] D. Koensgen, A. Mustea, I. Klaman et al., "Expression analysis and RNA localization of PAI-RBP1 (SERBP1) in epithelial ovarian cancer: association with tumor progression," Gynecologic Oncology, vol. 107, no. 2, pp. 266-273, 2007.

[53] J.-W. Ahn, S. Kim, W. Na et al., "SERBP1 affects homologous recombination-mediated DNA repair by regulation of CtIP translation during S phase," Nucleic Acids Research, vol. 43, no. 13, pp. 6321-6333, 2015.

[54] M. E. Schaner, D. T. Ross, G. Ciaravino et al., "Gene expression patterns in ovarian carcinomas," Molecular Biology of the Cell, vol. 14, no. 11, pp. 4376-4386, 2003.

[55] W. Sun, C. Guo, X. Meng et al., "Differential expression of PAI-RBP1, Clorf142, and COTL1 in non-small cell lung cancer cell lines with different tumor metastatic potential," Journal of Investigative Medicine, vol. 60, no. 4, pp. 689-694, 2012.

[56] B. W. Kunkle, C. Yoo, and D. Roy, "Reverse engineering of modified genes by bayesian network analysis defines molecular determinants critical to the development of glioblastoma," PLoS ONE, vol. 8, no. 5, article e64140, 2013.

[57] Y.-J. Lee, H.-M. Wei, L.-Y. Chen, and C. Li, "Localization of SERBP1 in stress granules and nucleoli," The FEBS Journal, vol. 281, no. 1, pp. 352-364, 2014.

[58] P. Valadez-Cosmes, L. Germán-Castelán, A. González-Arenas, M. A. Velasco-Velázquez, V. Hansberg-Pastor, and I. CamachoArroyo, "Expression and hormonal regulation of membrane progesterone receptors in human astrocytoma cells," Journal of Steroid Biochemistry and Molecular Biology, vol. 154, pp. 176185, 2015. 

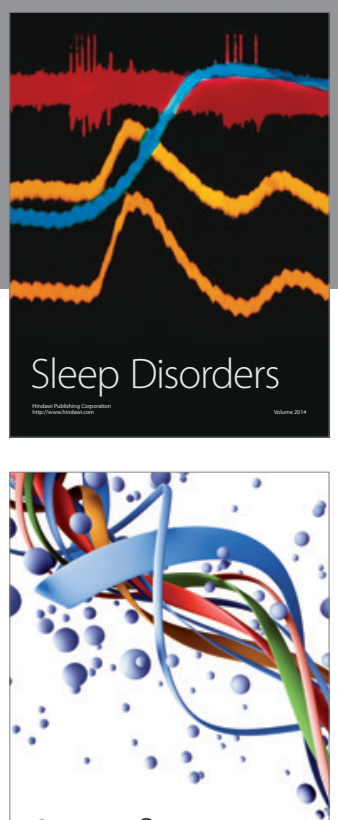

Scientifica
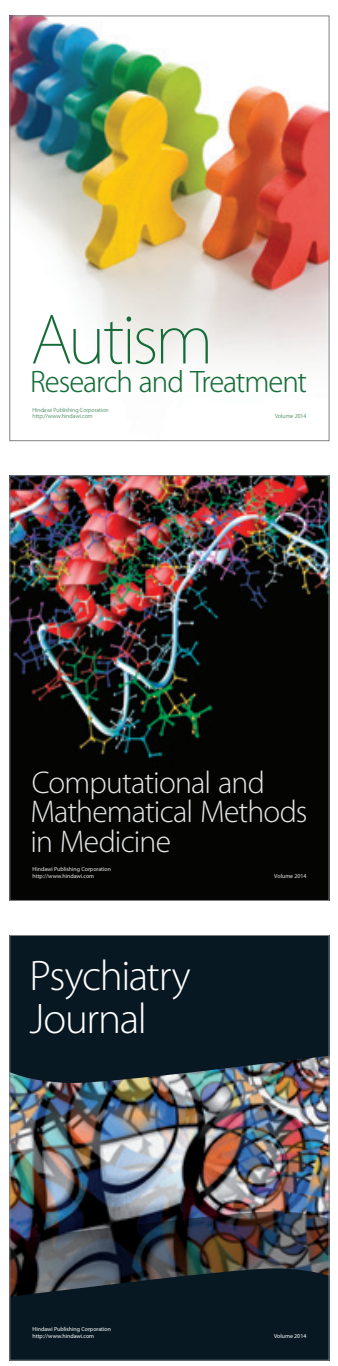
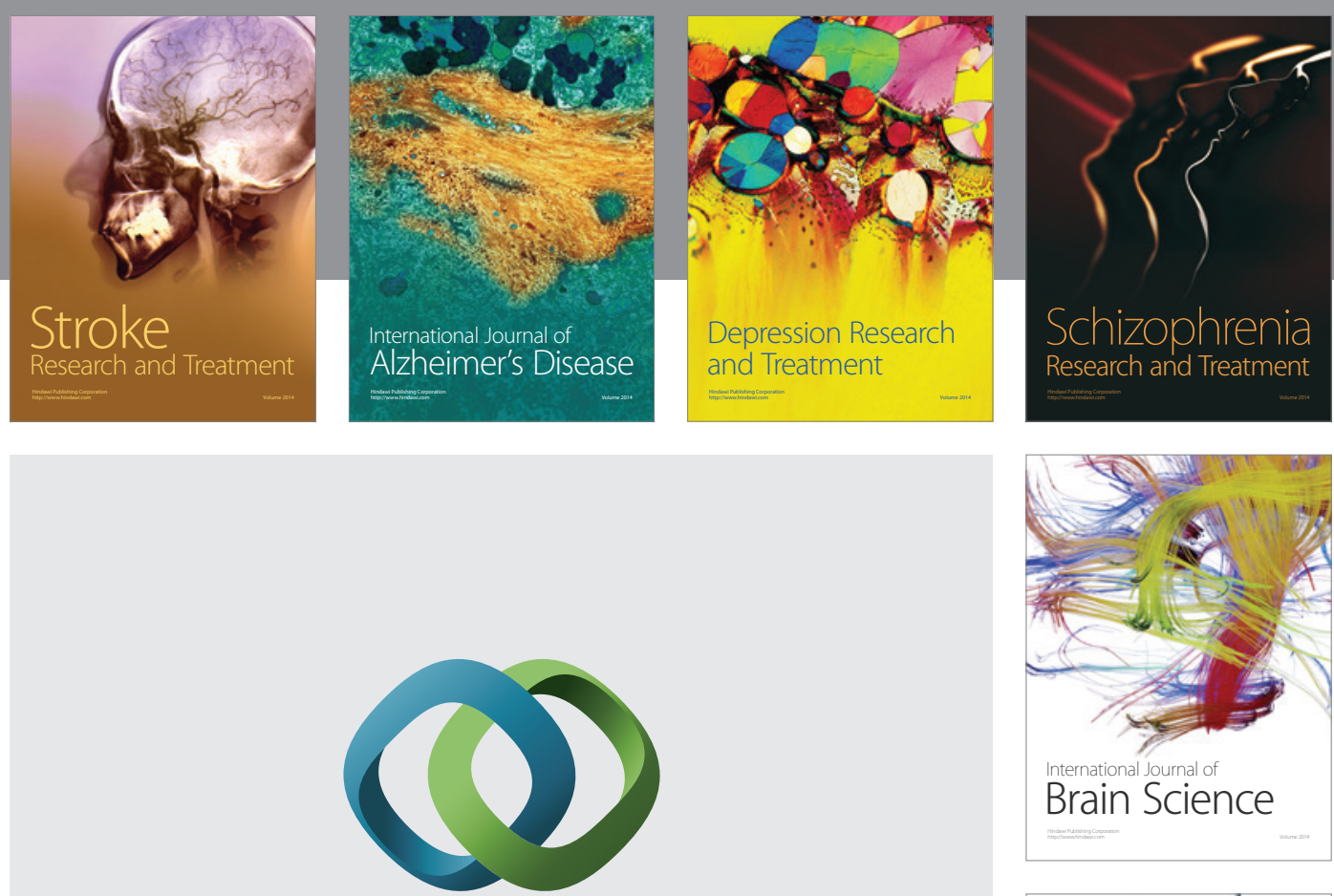

\section{Hindawi}

Submit your manuscripts at

http://www.hindawi.com
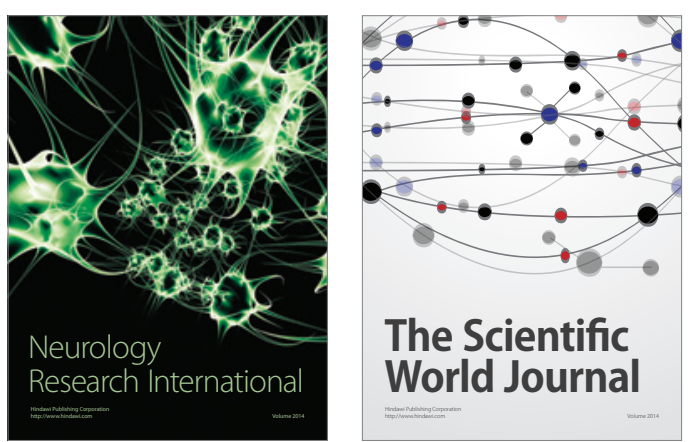

The Scientific World Journal

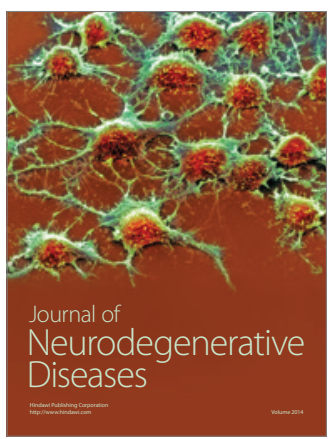

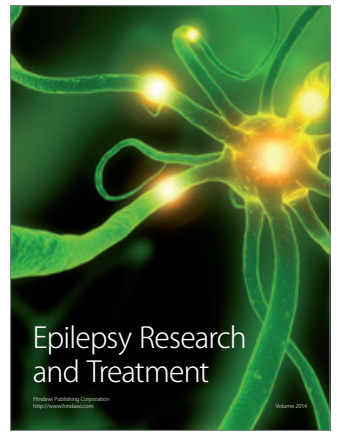

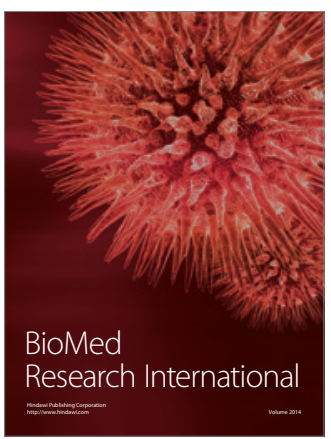

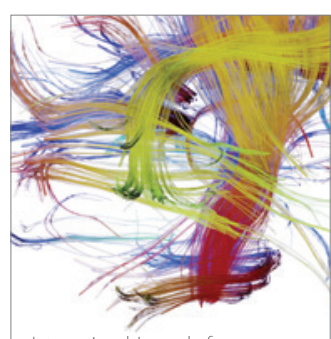

Brain Science

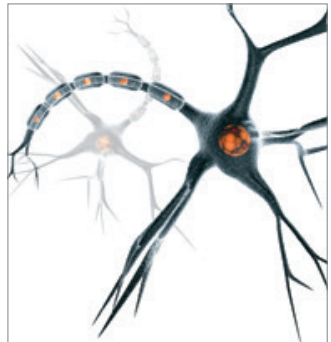

Neural Plasticity
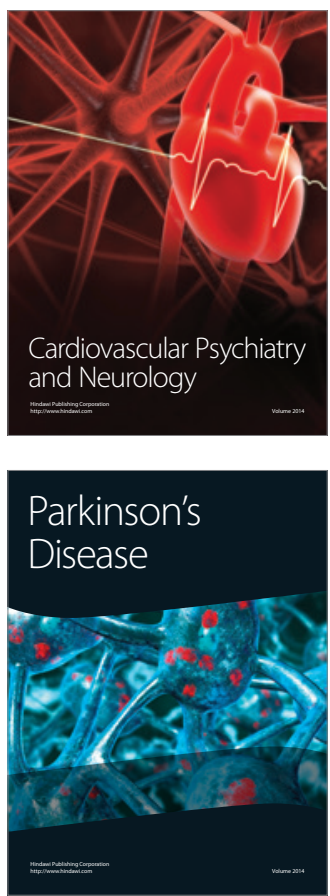